\title{
Potential in heavy oil biodegradation via enrichment of spore forming bacterial consortia
}

\author{
Saif N. Al-Bahry ${ }^{1} \cdot$ Yahya M. Al-Wahaibi $^{2}$ Balqees Al-Hinai ${ }^{1}$. \\ Sanket J. Joshi ${ }^{1,3} \cdot$ Abdulkadir E. Elshafie $^{1} \cdot$ Ali S. Al-Bemani ${ }^{2}$. \\ Jamal Al-Sabahi ${ }^{4}$
}

Received: 31 August 2015/Accepted: 17 January 2016/Published online: 4 February 2016

(c) The Author(s) 2016. This article is published with open access at Springerlink.com

\begin{abstract}
It is quite challenging to recover heavy crude oil due to its high viscosity and long chain hydrocarbon contents. In this study the isolation of thermophilic bacterial consortia from crude oil contaminated soil samples and their ability to degrade heavy crude oil were investigated. Thermophilic spore forming bacteria were inoculated with heavy oil in minimal salt media. Maximum growth was observed on 21 st day of incubation at $40{ }^{\circ} \mathrm{C}$. Samples were analyzed for biosurfactant production, where a substantial decrease in surface tension and interfacial tension was not observed. A well-assay was used to check the potential of bacterial consortia for oil-clearing zones on oil agar plate with bacterial cultures and their cell-free filtrates. 16S rRNA sequencing of 27 isolates from oil contaminated soil showed that isolates belonged to three classes: Alphaproteobacteria, gamma-proteobacteria and Bacilli. Scanning electron microscopy showed that the oil utilizing bacteria were rod-shaped with rough surface and fimbria. Gas chromatography analysis of treated oil after 21 days showed that bacterial consortia efficiently degraded heavy crude oil to light hydrocarbons ranging from $\mathrm{C} 11-\mathrm{C} 27$, from initial C37+ carbon chain of untreated controls. These bacterial consortia showed potential in heavy crude
\end{abstract}

Yahya M. Al-Wahaibi

ymn@squ.edu.om

1 Department of Biology, College of Science, Sultan Qaboos University, Muscat, Oman

2 Petroleum and Chemical Engineering Department, College of Engineering, Sultan Qaboos University, Muscat, Oman

3 Central Analytical and Applied Research Unit, College of Science, Sultan Qaboos University, Muscat, Oman

4 Central Analytical Lab, College of Agricultural and Marine Sciences, Sultan Qaboos University, Muscat, Oman oil biodegradation by breaking it down to smaller hydrocarbon composition.

Keywords Heavy crude oil · Bacterial consortia - Well assay · Gas chromatography

\section{Introduction}

Crude oil is the major source of energy in the world. The technologies, which improve the recovery efficiency and reduce environmental impacts, will be promising alternative to traditional oil recovery technologies. Biotechnology is considered as a new field recently introduced to the oil industry for various applications (Vazquez-Duhalt et al. 2002). Petroleum is a complex mixture of hydrocarbons and other organic compounds (Hamme et al. 2003). Crude oil is classified for economic value according to American Petroleum Institute (API) gravity, based on a surface measurement of the specific gravity of degassed oil. API gravity of heavy oils are 20 or less whereas a typical light oil is around 36-38 API (Head et al. 2003). Heavy oil is a thick, black, sticky fluid with high viscosities and densities compared to conventional oil. It generally contains high carbon, sulfur, and heavy metals. Al-Sulaimani et al. (2011) reported that around 2 trillion barrels of conventional light crude oil and 5 trillion barrels of heavy crude oil still remain in reservoirs worldwide. The oil fields of South Oman are reported to contain heavier crude oil, and significant discoveries of heavy oil-around 7+ billion barrels, Stock Tank Oil Initially In Place (STOIIP) in early 1990s led to a greater emphasis on their development (Nadyal et al. 1983). The average oil viscosity at a reservoir temperature of $50{ }^{\circ} \mathrm{C}$ varies from 1200 to $3600 \mathrm{cp}$ (Malik et al. 2010). Crude petroleum exists in the complex capillary network of oil 
reservoirs. Traditional recovery technologies (primarynatural pressure drive of the reservoir and secondary-fluid injection) can recover a maximum of $40-50 \%$ of the oil. Whereas in tertiary recovery-chemicals (polymer, alkaline and surfactants) and thermal energy (steam, combustion and hot water) are used to recover trapped crude oil. Microbial Enhanced Oil Recovery (MEOR) is a tertiary recovery technique, which involves the use of microbes and their metabolic products including biosurfactants, biopolymers, biomass, acids, solvents, gases and enzymes to increase the recovery of crude oil from depleted and marginal reservoirs (Behlülgil and Lu 2002; Bryant 1987; Sen 2008). Armstrong et al. (2015) studied the MEOR mechanisms of bioclogging and interfacial tension (IFT) reduction effects of pore morphology on residual oil mobilization. They reported that bioclogging with IFT reduction is the most effective MEOR treatment option in terms of enhancing oil recovery (EOR). Le et al. (2015) reported that MEOR has been shown to increase oil recovery by approximately 3-10 \%, during field trials and laboratory tests. They also reported the progress in pilot testing of MEOR applications in the Daqing oilfield of north China, where over the past decade, different MEOR technologies were developed, and cumulative oil increments have reached more than $1.2 \times 10^{5}$ times using these methods. Microorganisms use long-chain $n$-alkanes as carbon and energy source and higher rate of hydrocarbons utilization is also reported by bacterial consortium from oil exposed environments (Beilen et al. 2003; Bentoa et al. 2005; Geetha et al. 2013; Kebria et al. 2009). Due to microbial growth and polymer production, fluid components of oil are altered and viscosity reduction is achieved by degradation of oil components. Montiel et al. (2009) reported that oxidization and bio-upgrading of asphaltenes is the promising way to enhance fluidity and pumping of heavy crude oil. Still microbial systems have not been developed as a commercial service for heavy oil recovery because there are little data available or research specifically with heavy oil to support the commercialization. Microbial enzymes like peroxidase and lactase can also be used to treat heavy oil (Montiel et al. 2009). Enzymes like hydrolase and oxidoreductase breaks a covalent bond in their substrate adding a water molecule in the process (Harris and McKay 1998). Jumpstart Energy Services in USA developed Greenzyme ${ }^{\circledR}$-an enzymebased enhanced oil recovery. It is able to reduce paraffin waxy components and viscosity. Enzyme active site attaches to the oil and catalyzes it, so larger oil droplets are broken into smaller ones allowing more oil release and improved mobility and permeability.

The aim of this work was to isolate and identify sporeforming bacterial consortia from oil contaminated soil samples and explored its potential in biological upgrading of heavy crude oil.

\section{Materials and methods}

\section{Sample collection}

Oil contaminated soil samples were collected from seven different oil wells from Oman (well-19, well-14, well-28.1, well-28.2, Wasta well, Wafra well and oil-based mud collected from dumping area near oil reservoir) and heavy crude oil samples (API 16) were kindly provided by a local oil company in Oman.

\section{Isolation of bacterial consortia}

One gram of each soil samples was added to $15 \mathrm{ml}$ of sterile distilled water and heated at $85{ }^{\circ} \mathrm{C}$ for $30 \mathrm{~min}$, to eliminate the majority of non-spore forming bacteria. Aliquots of $2 \mathrm{ml}$ sterile heavy crude oil and $1 \mathrm{ml}$ diluted soil samples were inoculated in $250 \mathrm{ml}$ Erlenmeyer flasks each containing $50 \mathrm{ml}$ of one of the following minimal media: M6 (Mukherjee et al. 2009), M7 (Cooper et al. 1981) and M8 (Nazina et al. 2005). The compositions of media used are M6 $(\mathrm{g} / \mathrm{l}): \mathrm{NaCl}, 0.01 ; \mathrm{K}_{2} \mathrm{HPO}_{4}, 2.2 ; \mathrm{KH}_{2} \mathrm{PO}_{4}, 0.14 ; \mathrm{CaCl}_{2}$. $2 \mathrm{H}_{2} \mathrm{O}, 0.04 ; \mathrm{MgSO}_{4}, 0.6 ; \mathrm{NH}_{4} \mathrm{NO}_{3}, 3.3 ; \mathrm{FeSO}_{4}, 0.2$; trace mineral solution, $0.5 \mathrm{ml} / \mathrm{l}$. M7 (g/l): $\mathrm{KH}_{2} \mathrm{PO}_{4}, 4.083$; $\mathrm{MgSO}_{4}, 0.197 ; \mathrm{NH}_{4} \mathrm{NO}_{3}, 4.002 ; \mathrm{NaHPO}_{4}, 7.119$; trace mineral solution, $1 \mathrm{ml} / \mathrm{l}$. $\mathrm{M} 8$ (g/l): $\mathrm{NaCl}, 7 ; \mathrm{K}_{2} \mathrm{HPO}_{4}, 0.09$; $\mathrm{KH}_{2} \mathrm{PO}_{4}, 0.21 ; \mathrm{NH}_{4} \mathrm{Cl}, 0.8 ; \mathrm{MgCl}_{2} .5 \mathrm{H}_{2} \mathrm{O}, 0.2 ; \mathrm{CaCl}_{2} .2 \mathrm{H}_{2} \mathrm{O}$, $0.05 ; \mathrm{NaHCO}_{3}, 2.2$; trace mineral solution, $1 \mathrm{ml} / \mathrm{l}$. Respective uninoculated minimal media flasks with heavy crude oil were also incubated as negative controls. All flasks were incubated aerobically at $40{ }^{\circ} \mathrm{C}$ on rotary shaker at $160 \mathrm{rpm}$ for up to 21 days and samples were analyzed at 3, 7, 17 and 21 days for biosurfactant production (surface tension-ST and interfacial tension-IFT), growth measurement (by measuring optical density at $660 \mathrm{~nm}-\mathrm{OD}_{660}$ ), well assay on crude oil containing agar plates, and gas chromatography analysis. For isolating individual bacteria from the consortia, $0.1 \mathrm{ml}$ of inoculum was taken from 21 days grown culture media and plated on M7 agar plates, with heavy crude oil as a carbon source, and incubated at $40{ }^{\circ} \mathrm{C}$ for 7-12 days. Isolates obtained were further streaked on LuriaBertani (LB) agar plates and checked for purity prior to subsequent molecular analysis. The isolated bacteria from different consortia were morphologically analyzed (using scanning electron microscopy) and identified by molecular identification (using 16S rRNA sequencing).

\section{Analytical techniques}

\section{ST, IFT and growth measurement}

ST and IFT were analyzed using a Pendant Drop Tensiometer (DSA100, Krüss, Germany). The IFT was 
measured by immersing the sample into n-hexadecane (Sigma, USA) as embedding light phase. All measurements were carried out in triplicates at ambient temperature $\left(25^{\circ} \mathrm{C}\right)$ and pressure $(1 \mathrm{~atm})$ where the averages of three independent readings are reported. The growth was analyzed by measuring optical density at $660 \mathrm{~nm}$ (Heliose Spectrophotometer, Thermo Spectronic, USA).

\section{Well assay}

The ability of bacterial strains to degrade heavy crude oil was investigated by carrying out the well assay experiments. Filtered and non-filtered aliquots of each sample were used for this assay to check the difference in degradation of oil between bacteria and their extracellular metabolites (for e.g., enzymes). Wells of $0.5 \mathrm{~cm}$ diameter were made in M7 agar plates with heavy crude oil. Samples were filtered with $0.22 \mu \mathrm{m}$ sterile filters, to remove all bacteria. Approximately $0.1 \mathrm{ml}$ of filtered and non-filtered aliquots from each samples were inoculated in wells and incubated for 7 days at $40{ }^{\circ} \mathrm{C}$ under aerobic conditions. For each samples the experiments were performed in triplicates. The clear zones were measured according to the method of Zhang et al. (2004).

\section{Scanning electron microscopy of bacteria}

Bacterial species which have ability to grow on heavy oil were examined by scanning electron microscope. A loopful of each of the isolated colonies from M7 agar plates containing heavy oil was transferred to $3 \mathrm{~cm}$ diameter wells, containing $5 \mathrm{ml}$ of Luria broth. After $24 \mathrm{~h}$ incubation at $40{ }^{\circ} \mathrm{C}$, the bacteria grew and adhered to the glass surface. Karnovsky's fixative (2.5\% gluteraldehyde, $4 \%$ paraformaldehyde, $1 \mathrm{M} \mathrm{Na-cacodylate}$ buffer, $\mathrm{pH}$ 7.2) was used to fix bacteria for $2 \mathrm{~h}$ at $4{ }^{\circ} \mathrm{C}$. It was washed three times with $1 \mathrm{M}$ Na-cacodylate buffer with additives ( $1 \mathrm{~N} \mathrm{NaOH}, 1 \mathrm{~N} \mathrm{HCl}$, sucrose, $\mathrm{CaCl}_{2}$, and $\mathrm{MgCl}_{2}$ ), $\mathrm{pH} 7.2$ for $15 \mathrm{~min}$ at room temperature. It was post-fixed in aqueous $1 \%$ osmium tetroxide solution for $1 \mathrm{~h}$ at room temperature. Then it was washed twice with distilled water for $15 \mathrm{~min}$ at room temperature. It was dehydrated through ethanol series-wash at room temperature: $25,50,70,90 \%$ and four changes of $100 \%$, for $15 \mathrm{~min}$ at each change. Samples were dried using hexamethyldisilazane (HMDS): the last $100 \%$ ethanol solution was replaced with HMDS and left for $10 \mathrm{~min}$ and air-dried in the hood for 20-30 min. Samples were sputter-coated with gold $(\mathrm{Au})$ for $60 \mathrm{~s}$, and were observed in SEM (JOEL Scanning Electron Microscope 5600, Japan) at College of Medicine, Sultan Qaboos University, Oman.

\section{DNA extraction, amplification and sequencing}

For identifying cultivable isolated bacteria from different consortia, DNA was extracted from pure colonies using
Ultra Clean Soil DNA isolation Kit (MO BIO Laboratories, Inc, San Diego, USA), as directed by manufacturer (Yamane et al. 2008). One percent (1\%) agarose gel was used to view the extracted DNA. Purified DNA samples were used as templates for polymerase chain reactions (PCR). Universal bacterial primers 27F (5' AGA GTTTGATCCT GGCTCAG ' 3 ) and 1492R (5'GCYTACCTTGTTACGAC TT '3) were used for amplification of 16S rRNA gene fragment. The PCR amplification were done using 1 cycle of $3 \mathrm{~min}$ at $94{ }^{\circ} \mathrm{C}$, followed by 35 cycles of $1 \mathrm{~min}$ at $94{ }^{\circ} \mathrm{C}$, 2 min at $53{ }^{\circ} \mathrm{C}$ and 2 min at $72{ }^{\circ} \mathrm{C}$, followed by one cycle of $7 \mathrm{~min}$ at $72^{\circ} \mathrm{C}$ in a thermal cycler (Model 2720, Applied Biosystems, USA). First Purification was done using QIAquick PCR purification kit (QIAGen), and second PCR reaction (sequence reaction) was performed using $2 \mu \mathrm{l}$ of the first PCR products as template, $2 \mu \mathrm{l}$ of BigDye (Applied Biosystems, USA), $1 \mu 1$ of $5 \times$ sequence buffer, $3 \mu \mathrm{l}$ of primers $(27 \mathrm{~F}, 1492 \mathrm{R}, 515 \mathrm{~F}$ ), and $2 \mu \mathrm{l}$ of water. The PCR amplification was done using 1 cycle of $20 \mathrm{~s}$ at $96{ }^{\circ} \mathrm{C}, 10 \mathrm{~s}$ at $96{ }^{\circ} \mathrm{C}, 5 \mathrm{~s}$ at $50{ }^{\circ} \mathrm{C}$ and $4 \mathrm{~min}$ at $60{ }^{\circ} \mathrm{C}$ in a thermal cycler (Model 2720, Applied Biosystems, USA). Second purification was performed using DyeEX Kit (QIAGEN Inc., USA). Sequence reaction was performed on Sultan Qaboos University, College of Science, department of Biology using 3130 $x$ Genetic Analyzer (Applied Biosystems-Hitachi, USA). For phylogenetic analysis, partial 16S rRNA gene sequences were assembled in a contiguous sequence using ChromasPro v 1.41. Identification was achieved by comparing the contiguous $16 \mathrm{~S}$ rRNA gene sequence (1000 bp in length) with sequence data from reference available at the public databaseNCBI GenBank using BLAST sequence match. The sequences were aligned using ChromasPro. Evolutionary distances were derived from sequence pair dissimilarities calculated as implanted in MEGA 5 (Tamura et al. 2011). The phylogenetic reconstruction was done using the neighbor-joining (NJ) algorithm and maximum likelihood tree with bootstrap value calculated from 1000 replicates run.

\section{Gas chromatography analysis}

The crude oil and the alkane fractions were analyzed by gas chromatography-GC/MS (Perkin Elmer-Clarus 600). The experimental conditions were: capillary column-HP5 MS (HP\#19091S-433), $30 \mathrm{~m} \times 250 \mu \mathrm{m} \times 0.25 \mu \mathrm{m}$ with helium as a carrier gas; column temperature $-80{ }^{\circ} \mathrm{C}$ to $290{ }^{\circ} \mathrm{C}$ for $30 \mathrm{~min}$ with $10.0{ }^{\circ} \mathrm{C} / \mathrm{min}$ increment and hold at $240{ }^{\circ} \mathrm{C}$ for $30 \mathrm{~min}$; the injector temperature $-290{ }^{\circ} \mathrm{C}$. Individual components present in the alkane fraction were determined by matching the retention time with alkane standards (C7-C30 Saturated Alkanes standards$1000 \mu \mathrm{g} / \mathrm{ml}$ in hexane, Supelco Analytical, USA). Samples 
were fractionated on activated silica-gel columns $(1.5 \mathrm{~cm}$ diameter, $15 \mathrm{~cm}$ length) filled with slurry of 30-50 mesh silica gel in dichloromethane. The concentrated sample (in dichloromethane) was placed on the column. The oil fractions were collected in separate flasks and were concentrated (at $60{ }^{\circ} \mathrm{C}$ ) by rotary evaporator (Büchi, Switzerland). The concentrated oil was dissolved in dichloromethane and analyzed by GC.

\section{Results}

The increase in bacterial population growing on crude oil is clear evidence that bacterial consortia can utilize crude petroleum-oil hydrocarbon as a sole source of carbon and energy. Three different types of reported minimal salt media (M6, M7 and M8) were used to enrich bacterial consortia containing heavy crude oil as a carbon source. Out of three minimal media, M7 showed somewhat better growth during initial '21 day' experiments (data not shown), and thus was further utilized for experiments. Samples were collected at 3, 7, 17 and 21 day intervals and checked for growth. Highest growth was observed on 21st day from majority of samples, except from 'oil-based mud sample', where good growth was observed starting from 3rd day, and no further difference was observed till 21st day (Fig. 1).

The reduction in ST was observed from bacterial consortia of 'oil-based mud' and 'w28.2' samples. The ST was reduced to $<50$ from $70 \mathrm{mN} / \mathrm{m}$, whereas, other bacterial consortia from rest of the samples showed ST values around $\geq 55 \mathrm{mN} / \mathrm{m}$. Whereas, much change were not observed in IFT values for all of the consortia from different samples, all showed values $\leq 28 \mathrm{mN} / \mathrm{m}$ from $35 \mathrm{mN} / \mathrm{m}$.

All seven bacterial consortia from different samples were screened for heavy oil degradation by well assay. As shown in Fig. 2, it was observed that bacterial consortia from 'w14' and 'wasta' samples exhibited larger clearing zones, as compared to rest of the bacterial consortia.

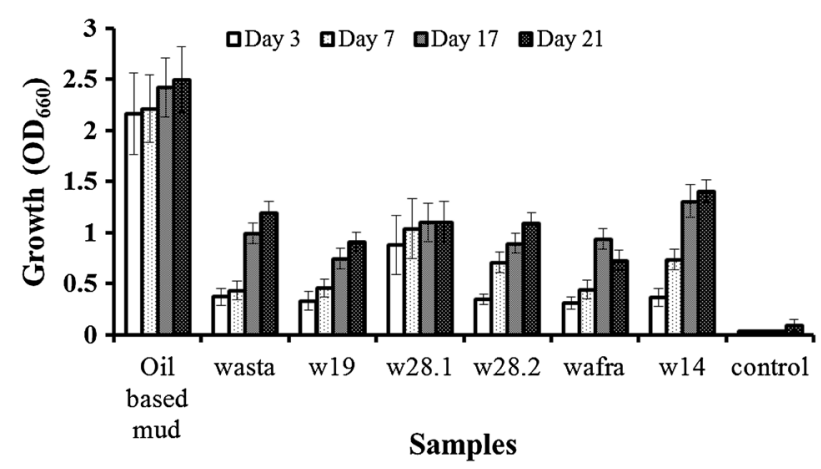

Fig. 1 The growth profile $\left(\mathrm{OD}_{660}\right)$ of bacterial consortia in minimal salt media-M7, with heavy crude oil during 21 days incubation at $40{ }^{\circ} \mathrm{C}$
Whereas, cell-free filtrate of bacterial consortia from 'oilbased mud' and 'wasta' samples gave larger zones of clearance. Bacterial consortia from ' $w 19$ ' samples gave smallest zone of clearance and no-zone of clearance was observed from their cell-free filtrates (Fig. 2).

A total of 27 different bacterial colonies were isolated from heavy crude-oil and bacterial consortia from 7 oil contaminated samples, which were able to grow on heavy oil. According to PCR amplification, sequencing of $16 \mathrm{~S}$ rRNA gene and its alignment in BLAST revealed that the isolates belonged to three major bacterial classes: Bacilli, gamma-proteobacteria and alpha-proteobacteria. Isolates belonged to six genera; Acinetobacter, Bacillus, Pseudomonas, Bosea, Azospirillum and Nitratireductar. Table 1 shows the identified isolates and the closest strains from NCBI database, with similarity percentage of identity.

Maximum likelihood trees were constructed by Kimura 2-parameter method using MEGA ver.5 programme (Fig. 3). Boot strap value larger than 50 in tree give an indication that isolate is same to reference sequence. BC11 sample may be new Acinetobacter sp., due to small boot strap value. Azospirillum, Nitratireductor and Bosea genera belong to Alpha-proteobacteria class. From phylogeny tree, BC-15 and BC-10 isolates were identified as Azospirillum rugosum and Bosea thioxidans, respectively, as boot strap value is 100 for both of them. The third class mainly consisted of Bacillus genus. BC-14, BC-5, and BC-21 were identified as Bacillus firmus, Bacillus foraminis and Bacillus licheniformis. Figure 4 shows the percentage frequency of occurrence of different bacteria isolated from different soil samples and heavy crude oil.

Bacterial cells morphology was examined by SEM. Bacillus licheniformis isolated from ' $w 28$ ' samples, were arranged in binary with rough surface (Fig. 5a), B. siralis isolated from 'oil-based mud' sample were arranged in long chain and connected to each other by thin filaments similar to fimbriae (Fig. 5b). Figure 5c shows B. licheniformis isolated from 'wasta' soil sample, were also found

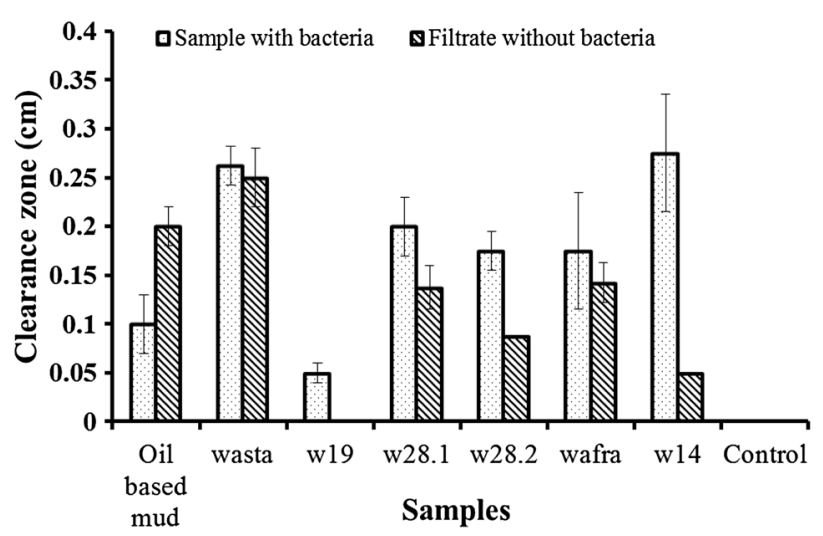

Fig. 2 Oil clearance zones of seven bacterial consortia and their 'cell-free filtrates' on M7 agar plates containing heavy crude oil 
Table 1 Closest relatives of cultured bacterial isolates from oil contaminated soil

\begin{tabular}{|c|c|c|c|c|}
\hline $\begin{array}{l}\text { Isolate } \\
\text { number }\end{array}$ & $\begin{array}{l}\text { Isolates } \\
\text { names }\end{array}$ & $\begin{array}{l}\text { Closest cultured representative from NCBI } \\
\text { database }\end{array}$ & $\begin{array}{l}\text { GenBank accession no. of the closest cultured } \\
\text { representative }\end{array}$ & $\begin{array}{l}\% \text { Similarity } \\
(\%)\end{array}$ \\
\hline $\mathrm{BC} 1$ & W14-1 & Bacillus licheniformis, strain NJ-5 & FJ435674 & 99 \\
\hline $\mathrm{BC} 2$ & $\mathrm{H} 3$ & Bacillus licheniformis, strain GA8 & AY162136 & 95 \\
\hline $\mathrm{BC} 3$ & WAF & Bacillus subtilis, strain BHP6-1 & JF112298 & 99 \\
\hline BC4 & WAF-1 & Bacillus firmus, strain D1 & AJ491843 & 98 \\
\hline BC5 & H12 & Bacillus foraminis, strain CV53T & AJ717382 & 98 \\
\hline BC6 & WASTA-1 & Bacillus licheniformis, strain NJ-5 & FJ435674 & 95 \\
\hline BC7 & WAF-2 & Bacillus licheniformis, strain CGMCC 2876 & GQ148817 & 98 \\
\hline BC8 & $\begin{array}{r}\text { CRUDE } \\
\text { OIL-1 }\end{array}$ & Pseudomonas aeruginosa strain DQ8 & GU269267 & 100 \\
\hline BC9 & $\begin{array}{r}\text { CRUDE } \\
\text { OIL-2 }\end{array}$ & Pseudomonas stutzeri strain LS401 & PSU26417 & 99 \\
\hline $\mathrm{BC} 10$ & WASTA-2 & Bosea thiooxidans isolate $\mathrm{TJ} 1$ & AF508112 & 96 \\
\hline BC11 & MUD-1 & Acinetobacter junii strain S33 & AB101444 & 99 \\
\hline $\mathrm{BC} 12$ & W14-2 & Acinetobacter junii strain DSM 6964 & NR_026208 & 99 \\
\hline $\mathrm{BC} 13$ & WAF-3 & Acinetobacter junii & JN644576 & 99 \\
\hline $\mathrm{BC} 14$ & W28.1-1 & Bacillus firmus, isolate CV93b & AJ717384 & 98 \\
\hline $\mathrm{BC} 15$ & W19 & $\begin{array}{l}\text { Azospirillum rugosum, strain IMMIB AFH- } \\
6 \mathrm{~T}\end{array}$ & AM419042 & 93 \\
\hline BC16 & W28.2 & Nitratireductor $s p$ & GU111569 & 97 \\
\hline BC17 & MUD-2 & Bacillus siralis strain 171544 & NR_028709 & 95 \\
\hline BC18 & WASTA-3 & Bacillus firmus strain zou4 & DQ173158 & 99 \\
\hline BC19 & W14-3 & Bacillus licheniformis & GQ148817 & 93 \\
\hline $\mathrm{BC} 20$ & W28.2-1 & Bacillus licheniformis & GQ148817 & 99 \\
\hline $\mathrm{BC} 21$ & MUD-3 & Bacillus licheniformis & GU201863 & 98 \\
\hline $\mathrm{BC} 22$ & W28.1-2 & Bacillus firmus & AJ491843 & 98 \\
\hline $\mathrm{BC} 23$ & $\mathrm{H}-11$ & Bacillus licheniformis & DQ993676 & 99 \\
\hline $\mathrm{BC} 24$ & W28.1-3 & Bacillus firmus & AY833571 & 99 \\
\hline $\mathrm{BC} 25$ & WAF-4 & Pseudomonas reactans & HM104379 & 99 \\
\hline BC26 & W28.1-4 & Pseudomonas fluorescens & HQ880245 & 100 \\
\hline $\mathrm{BC} 27$ & W28.2-2 & Bacillus licheniformis & AF276309 & 99 \\
\hline
\end{tabular}

connected with fimbria and $B$. subtilis isolated from 'wafra' soil sample were arranged as long chains (Fig. 5d).

The consortia of 'wasta' soil samples showed larger zone of clearance on oil-agar plates, and thus were selected for GC analysis. The Fig. 6a shows the chromatogram of heavycrude oil, which is composed of hydrocarbons from $\mathrm{C1}-$ $\mathrm{C} 37+$ (also confirmed by supplying local oil company). Microbial treated heavy oil with 'wasta' bacterial consortium was broken down to hydrocarbons ranging from $\mathrm{C} 11$ to C27 (Fig. 6b). The maximum concentration of treated oil fractions was hydrocarbon with carbon chain-C15 (Fig. 7).

\section{Discussion}

Crude-oil will in all likelihood remain a major source of energy worldwide for the foreseeable future. Since the beginning of industrialization, continuous demand has driven oil producing countries to provide oil in huge quantities. But currently 'easily recoverable light oil' has peaked, and remaining 'heavy oil' reserves will be the key source to meet a big demand on energy. Heavy oil is thick dark fluid with high viscosity and density. Heavy oil requires more expensive and advanced technologies to recover and refine because of its high viscosity. Like most other neighboring Gulf countries, Sultanate of Oman also depends on oil resources as a pillar for its national economy. In Sultanate of Oman large heavy oil reserves were discovered in early 1990s, estimated at $7+$ billion barrels (Nadyal et al. 1983). These large but 'difficult to recover' heavy oil reservoirs holds the answer to Sultanates 'everdeveloping' economy. Crude oil is originally formed from remains of dead animals and plants which are degraded by microorganisms. ZoBell and his coworkers were the first to review the action of microorganisms on hydrocarbons, since then scientists have started exploring bacteria and 


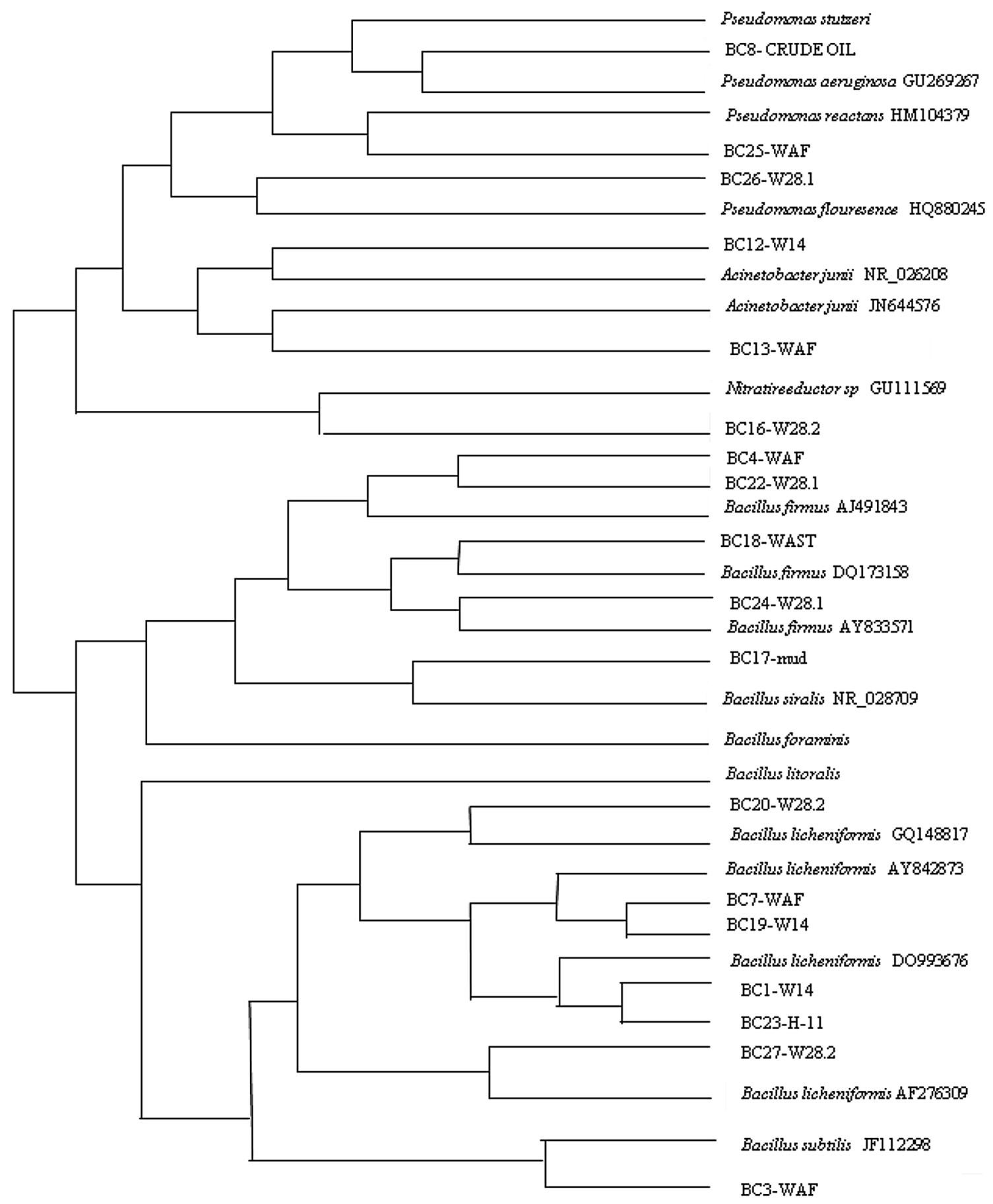

Fig. 3 Maximum likelihood derived phylogenetic tree of selected isolates from contaminated soil and related organisms. The length of the branch is proportional to the amount of inferred evolutionary change and the pairwise distance follow the sequence name

their metabolites in oil recovery or bioremediation of contaminated sites (Al-Sulaimani et al. 2011, 2012; Geetha et al. 2013).

Microbial permeability profile modification (MPPM) by selective plugging or bioclogging is one such mechanisms of MEOR applications (Al-Hattali et al. 2013). The selective plugging or bioclogging by the microbial biofilm growth in highly permeable zones of reservoirs or aquifers diverts water into low permeability zones (Surasani et al. 2013). The MPPM applications by bioclogging at the reservoir scale is still inhibited by a lack of understanding and advanced modeling and prediction tools. Researchers have reported a Reactive Transport Model (RTM) to understand controls of bioclogging processes in the silica 


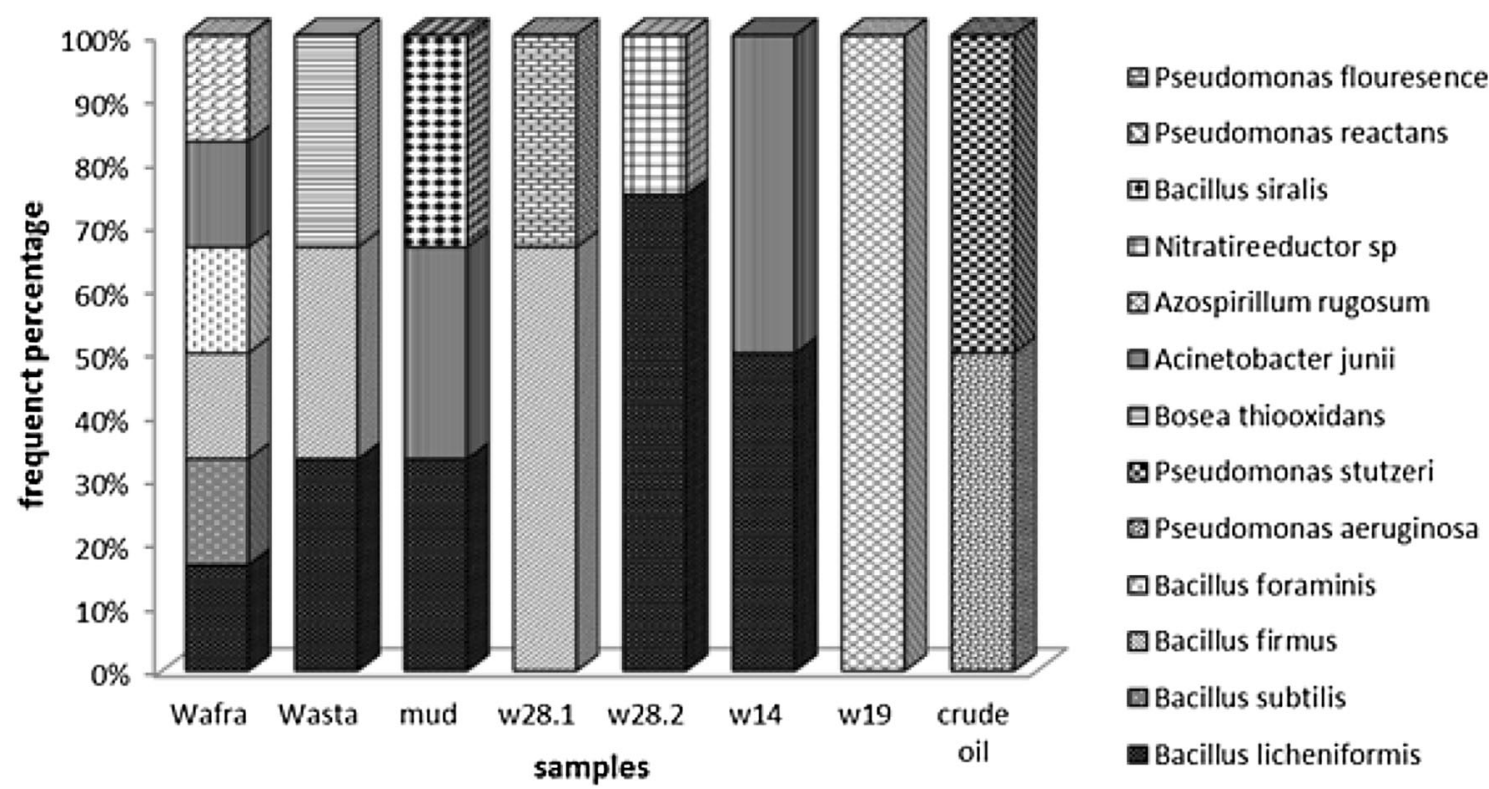

Fig. 4 Percentage frequency of occurrence of bacteria isolated from seven different oil contaminated soil samples and heavy crude oil sample

sand porous medium, carbonate formations and at the sandstone reservoir scale using L. mesenteroides as a model microorganism (Surasani et al. 2013; Vilcáez et al. 2013; Wu et al. 2014). They reported significant dextran formation and the associated porosity and permeability alterations which eventually diverted the injection water into low permeability zones. They observed between 10 to $75 \%$ bioclogging effectiveness, as measured by the percentage of the water diverted into the low permeability zones, depending on the injection conditions.

Al-Bahry et al. (2013) screened and studied the microbial consortia consisting of 33 genera and 58 species, from oil fields of Al-Wusta region, Oman. They reported that majority of the identified microorganisms were found to be anaerobic, thermophilic, and halophilic, and produced biogases, biosolvants, and biosurfactants as by-products, which may be good candidates for MEOR. In this study we explored isolation of spore-forming bacteria from oil-contaminated sites of Oman and their possible applications in biodegradation or upgrading of heavy-crude oil. In this investigation a 'selective enrichment' method was used to isolate thermophile spore-forming bacteria from oil contaminated soil samples. Seven oil contaminated soil samples were collected and boiled at $85^{\circ} \mathrm{C}$ to eliminate majority of vegetative non-spore forming bacteria. Samples were observed for 21 days incubation in three different minimal salt media, where one medium-M7 showed somewhat better growth than rest two media (data not shown). Thus, M7 was selected for further studies. The bacterial growth was strong evidence that bacterial consortia utilized heavy oil as carbon and energy sources. Higher growth was observed at the end of day 21 from all the samples. Mandri and Lin (2007) found a correlation between cell number and ability of degrading engine oil. Biria et al. (2007) found that at shorter incubation time, increase in the capillary number will be also less and, hence the oil production will also be reduced.

IFT and ST reduction are reported to have an important effect on light or heavy crude oil recovery by bacterial biosurfactants under laboratory experiments of core-flood or sand-pack column studies (Al-Sulaimani et al. 2012; Joshi and Desai 2013; Joshi et al. 2015). In this study, there was no much reduction in ST and IFT between treated samples and controls were observed, and only minor reduction in ST from day 17 and day 21 was observed. Illias et al. (2001) reported that Bacillus reduced IFT of medium containing kerosene up to 25 dynes $/ \mathrm{cm}$. We also observed IFT values around $\leq 28 \mathrm{mN} / \mathrm{m}$. Sepahy et al. (2005) reported slight increase in ST and IFT was observed at the early stationary phase of bacterial growth. This study showed that there was no drastic decrease in ST and IFT of these samples in M7 media with heavy oil, may be these bacterial consortia were unable to produce biosurfactant in these types of media and conditions.

The bacterial consortia which have the ability to utilize and degrade heavy oil were examined by well-assays. The heavy oil utilization ability was correlated with clearing zone diameter around each well in the plate after incubation for 7 days. Bacterial consortia from all seven contaminated sites showed varied positive results. There was a clear difference between clearing zones diameters when bacterial cells cultures or their cell-free filtrates were used. The highest clearing zone diameters were obtained from w14, wasta, w28.2, wafra, oil-based mud, and w19

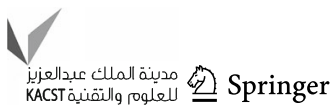


Fig. 5 SEM of a Bacillus licheniformis (from w28 sample); b Bacillus siralis (from oil-based mud sample); c $B$. licheniformis (from wasta soil sample) and $\mathbf{d}$ B. subtilis (from wafra soil sample)
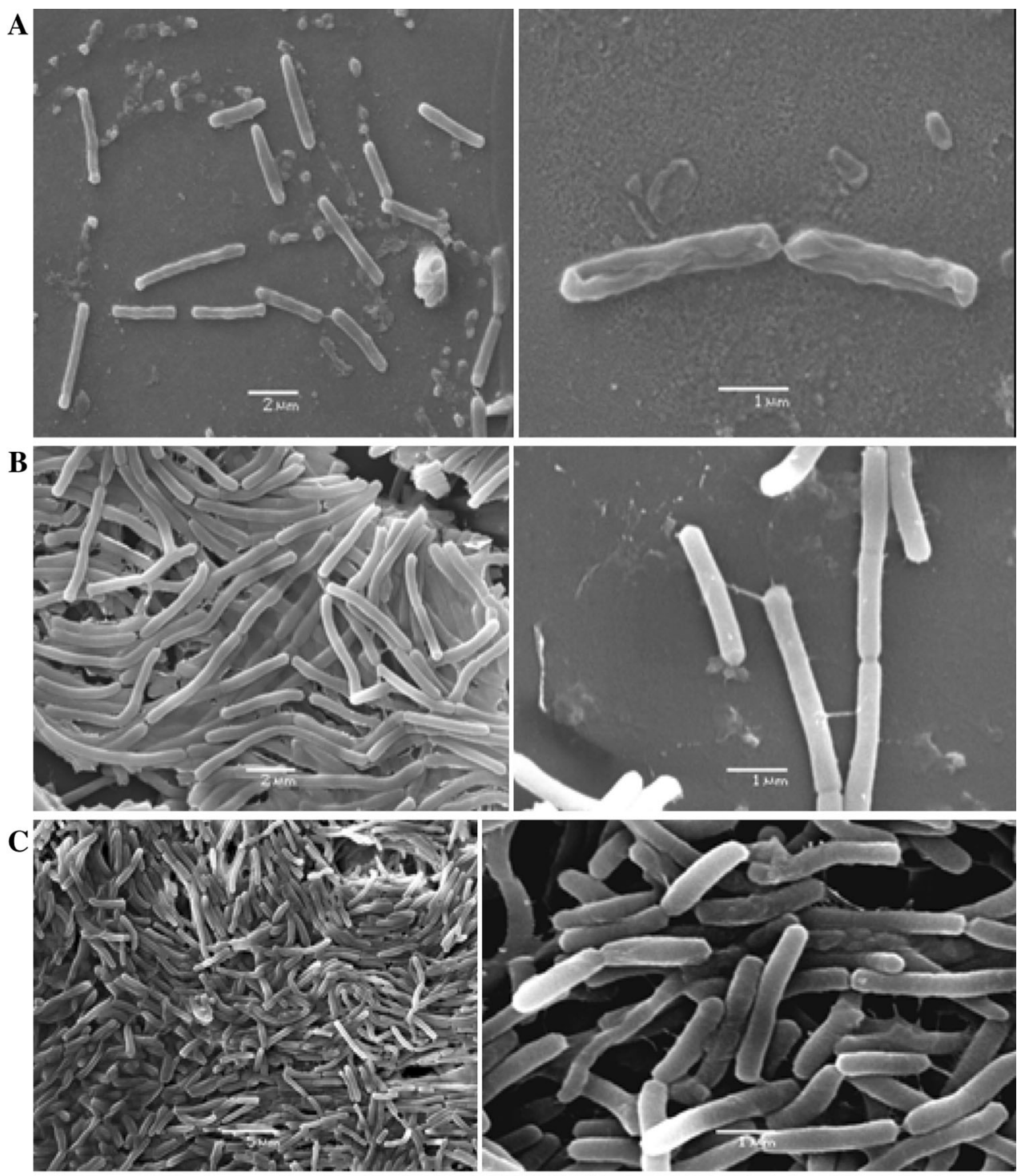

D
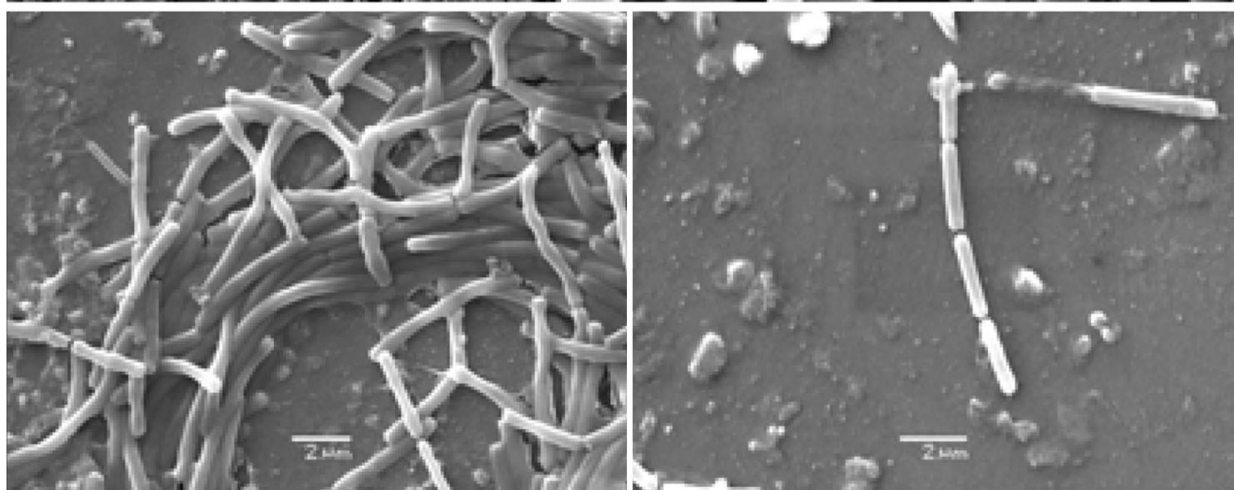

consortia, respectively. Cell-free filtrates of wasta, oilbased mud, wafra, w28.2, and w14 samples showed highest clearing zones, respectively, while 'w19' cell-free filtrate did not show any clearing zone. Bacterial cells consume oil as a carbon source and thus show clearing zones around their colonies. No clearing zones with abiotic control samples were found, which means that the clearance zones resulted from bacteria action and not because of other abiotic factors. Hasanuzzaman et al. (2004) reported that a clearance halo around Pseudomonas aeruginosa colony was observed after 3 days on an agar plate (with salad, olive, lard, and waste oils) and correlated to the presence of 

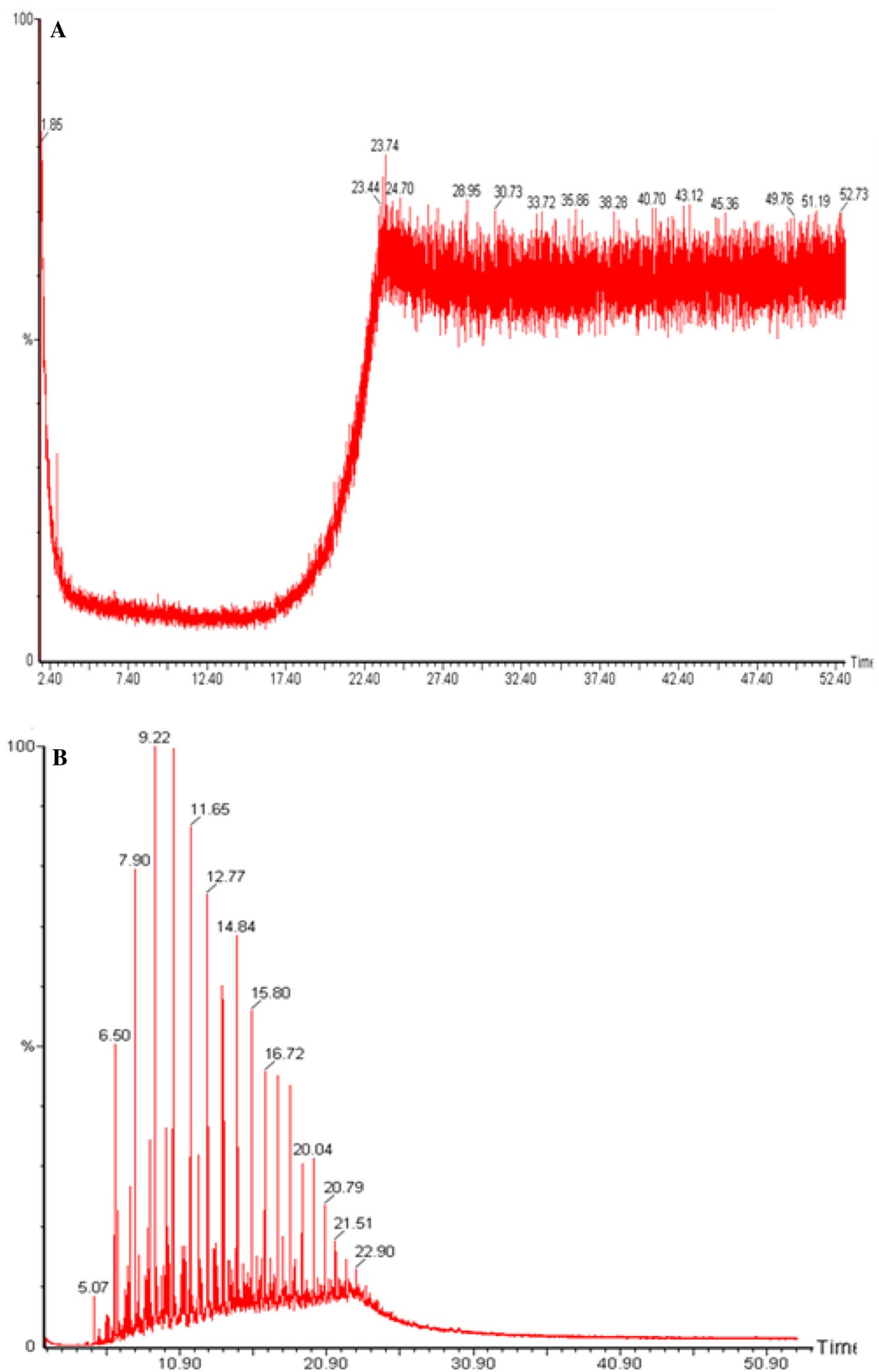

Fig. 6 The GC analysis of heavy crude oil: Abiotic control (a) and heavy crude oil treated with 'wasta' bacterial consortium (b) after 21 days 
Fig. 7 Main components of treated heavy crude oil after 'wasta' bacterial consortium growth

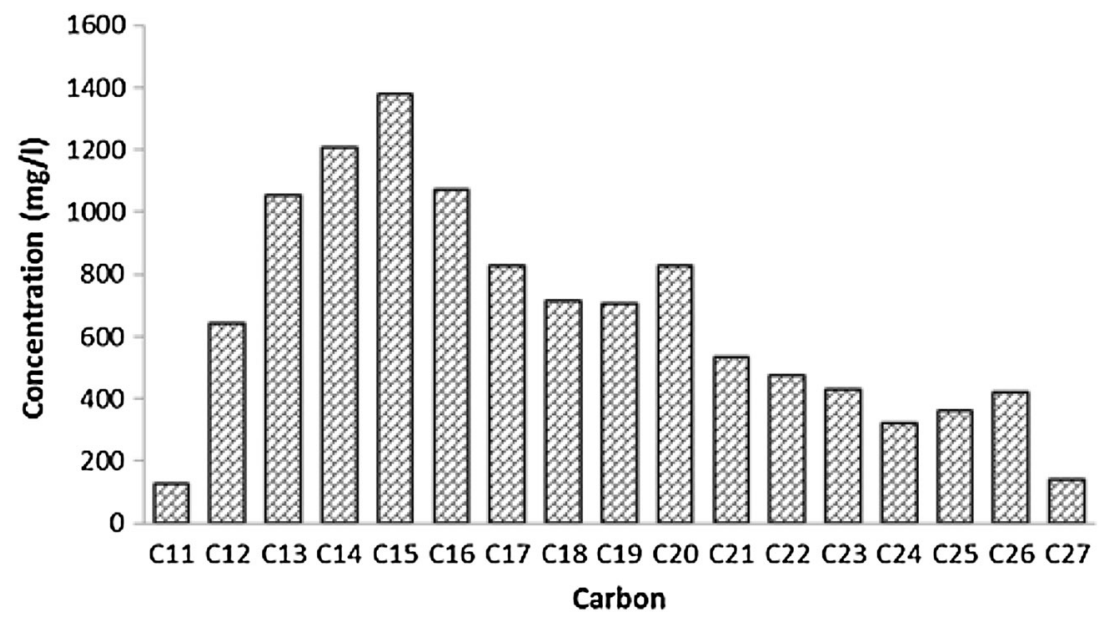

extracellular lipase enzyme. Satpute et al. (2008) found emulsified hole in coated plates with crude oil after incubation for 7-10 days with Bacillus subtilis and Pseudomonas. In agreement with previous studies, this study found clearing zones formation after 7 day with different bacteria consortia. Wasta sample which have mixture of $B$. licheniformis, B. firmus and Bosea thioxidants showed the largest clearing zones diameter in heavy oil. Zones formed after incubation with free cells filtrate, suggest that these types of bacteria produce extracellular compounds that break oil and produce clearing zones. Chandran and Das (2010) concluded that culture supernatant of Trichosporon asahii (yeast) when inoculated with diesel oil, produced clear halo. Rodrigues et al. (2006) correlated higher surface activity of biosurfactant solution with larger diameter produced by Lactococcus lactis. Ting et al. (2009) reported that Pseudomonas lundensis produced clearing zones when incubated with oil by metabolizing long-chain-length of alkanes. Based on the result of this experiment and previous studies, the presence of clearing zones in oil plates is an evidence of oil biodegradation by the bacterial cells themselves and also by their extracellular metabolicproducts.

A total 27 bacterial strains were identified by $16 \mathrm{~S}$ rRNA sequencing. Amplification and sequencing of $16 \mathrm{~S}$ rRNA revealed that these species belonged to six different genera as mentioned in Table 1. Phylogenetic trees showed that isolates belonged to three main classes; gamma-proteobacteria, alpha-proteobacteria and Bacilli. Bacillus spp. presented over $50 \%$ of the isolated cultivable flora. It is reported that the major genera of bacteria active in polluted soils as hydrocarbon-degraders are Pseudomonas, Bacillus, Serratia and Acinetobacter (Hamme et al. 2003; Nkwelang et al. 2008), gamma proteobacterium were reported in Rod Bay seawater contaminated with crude oil (Yakimov et al. 1997).
In this study Acinetobacter junii was isolated from contaminated soil and grew in heavy oil in agreement with previous studies. Acinetobacter spp. is one of the most efficient oil degraders. Pseudomonas aeruginosa, $P$. stut$z e r i, P$. reactans and $P$. fluorescens were isolated from soil and grew in heavy oil as many other studies revealed below. $P$. southpolaris and $P$. psychrotoleratus were detected by DGGE from oil contaminated soil (Evans et al. 2004). P. stutzeri was isolated from Antarctic soils and resembled the aromatic hydrocarbon-degradation (Saul et al. 2005).

Bacillus spp. is frequently the dominant species in environments exposed to different petroleum hydrocarbons. We also found Bacillus licheniformis, B. subtilis, $B$. firmus, B. foraminis, B. siralis, from different soil samples. Bacillus sp., was detected by DGGE from oil contaminated soil (Evans et al. 2004). Yakimov et al. (1997) reported that Bacillus licheniformis strain was isolated which grows on oil as a carbon source, which produced polymers and reduced surface tension.

In this study, Bosea thiooxidans was identified from 'wasta' sample. Seo et al. (2007) have reported isolation of Bosea thiooxidans from petroleum-contaminated soil that effectively degraded polycyclic aromatic hydrocarbons (PAHs). This study showed that a wasta consortium containing Bosea thiooxidans had the largest clearing zones and higher media viscosity reading. This may be caused by degradation ability of this strain.

Acinetobacter, Bacillus and Pseudomonas are found to be long chain hydrocarbon degrading bacteria (Kubota et al. 2008). Dioxygenase enzyme from Acinetobacter sp. utilized C12 to C20-alkenes (Maeng et al. 1996). Acinetobacter is also reported as capable to utilize $n$-alkanes with chain lengths ranging from $\mathrm{C} 10$ to $\mathrm{C} 40$ as a sole carbon source (Throne-Holst et al. 2007). So it is already known that these different bacteria isolate especially 
Acinetobater sp. from this study can grow in presence of heavy oil and break it down. Brevibacillus, Dietzia, Methylobacterium and Bacillus pumilus from the oil and formation water are reported to produce-monooxygenase, hydroxylase and oxidoreductase enzymes for oil epoxidation (da Cruz et al. 2010). In well assays, we observed oilclearance zones by cell-free extracts also, which could be because of some of these types of reported enzymes, which needs to be studied in further detail.

SEM of some of the isolated bacteria gave an overview of extracellular morphology of heavy oil utilizing bacteria isolated from oil contaminated soil. These bacteria were like rods arranged in long chain structure. Most of them have cellular extensions that may be used to attach hydrophobic compound and access them to cell metabolism. Surface proteins responsible for adhesion to hydrophobic nutrients are mainly found into fimbriae or distributed in a rough layer over the cell surface (Paul and Jeffrey 1985).

The GC analysis of untreated crude oil showed no clear isolated peaks. This may be because of heavy oil mainly consisted of long chains hydrocarbons $(\mathrm{C} 37+)$ as also confirmed by Oil Company. After 21 days of incubation with bacteria, GC analysis revealed that treated heavy oil components differed from untreated crude oil. Hydrocarbon fractions especially from $\mathrm{C} 12$ to $\mathrm{C} 27$ were detected after growth of 'wasta bacterial consortium'. Disappearance of long chain from GC output may be due to their degradation to light ones. Moran et al. (2000) reported that after treatment of oil with biosurfactant and B. subtilis O9, light carbon fraction ranged from $n-\mathrm{C} 12$ to $n$-C19, with a maximum between $n-\mathrm{C} 15$ and $n-\mathrm{C} 16$, and the heavy fraction started with $n$-C23 and had a maximum between $n$ C27 and $n$-C29 as detected by GC. Large molecules of aromatics, resin and asphaltic in the heavy oil are degraded extremely slowly in natural degradation process (Hozumi et al. 2000). In present study also we didn't observed much changes in the values of resins and asphaltenes (data not shown). Indigenous microorganisms of the California seawater degrade up to $80 \%$ of the lighter oils and up to $50 \%$ of the heavier oils (Atlas 1975). B. licheniformis isolated from heavy oils decreases the concentration of the $\mathrm{C} 25+$ group by degrading long-chained hydrocarbons. In this study, there was also a decrease in the concentration of light carbon groups, such as the C6-C11 groups. Decreases in light and heavy components lead to increase in the concentrations of the middle carbon groups. The chemical composition analysis of the oil samples showed that the microbes do degrade the long hydrocarbon chains into lighter hydrocarbons to use them as a carbon source. AlSayegh et al. (2015) reported isolation of bacterial isolates from an Omani oil field, which were able to degrade and transform heavy crude oil to lighter components. They reported that biodegradation and biotransformation processes lead to $16 \%$ additional oil heavy recovery. Premuzic and Lin (1999) found that crude heavy oil did not show any presence of light components, in comparison heavy oil treated with biocatalysts showed the presence of light chain components in gas chromatography analysis. Mixture of bacterial strains: Acinetobacter, Pseudomonas and Alcaligenes degraded heavy oil components. Beilen et al. (2003) found that Acinetobacter sp. grow on (C6C44) alkanes, Pseudomonas putida grow on (C5-C12) alkanes and Pseudomonas aeruginosa grow on (C5-C16) alkanes.

In conclusion, thermotolerant spore forming bacterial consortia were isolated from different crude oil contaminated soil samples in Oman. The bacterial consortia mainly consisted of Bacilli group. The consortia were able to grow on minimal media containing only heavy crude oil as carbon source. Samples were analyzed for biosurfactant production, but none of the samples showed substantial reduction in ST or IFT, which could be because of very low or no biosurfactant production by the bacterial consortia, in currently used 3 minimal salt media. Despite the lack of any noticeable decrease in ST or IFT, the consortia showed clearance of oil on oil agar plates in the well assay, which clearly showed a positive effect of either the bacterial consortia or their metabolites. Gas chromatography analysis of treated heavy oil with bacterial consortia isolated from 'wasta' samples, revealed significant degradation of heavy oil from $\mathrm{C} 37+$ hydrocarbons to lighter hydrocarbons with carbon chain C7-C27. This reduction in carbon chain is probably quite encouraging for enhanced oil recovery applications as well as heavy crude oil bioremediation purposes. Different bacterial isolates from this study may contribute in heavy oil recovery by breaking long hydrocarbons. It is further recommended to study and understand the active mechanism of bacterial metabolites (enzymes) which are responsible for breaking down of heavy oil.

Open Access This article is distributed under the terms of the Creative Commons Attribution 4.0 International License (http:// creativecommons.org/licenses/by/4.0/), which permits unrestricted use, distribution, and reproduction in any medium, provided you give appropriate credit to the original author(s) and the source, provide a link to the Creative Commons license, and indicate if changes were made.

\section{References}

Al-Bahry SN, Elshafie AE, Al-Wahaibi YM, Al-Bimani AS, Joshi SJ, Al-Maaini RA, Al-Alawai WJ, Sugai Y, Al-Mandhari M (2013) Microbial consortia in Oman oil fields: a possible use in enhanced oil recovery. J Microbiol Biotechnol 23:106-117

Al-Hattali R, Al-Sulaimani H, Al-Wahaibi Y, Al-Bahry S, Elshafie A, Al-Bemani A, Joshi SJ (2013) Fractured carbonate reservoirs 
sweep efficiency improvement using microbial biomass. J Petrol Sci Eng 112:178-184

Al-Sayegh A, Al-Wahaibi Y, Al-Bahry S, Elshafie A, Al-Bemani A, Joshi S (2015) Microbial enhanced heavy crude oil recovery through biodegradation using bacterial isolates from an Omani oil field. Microb Cell Fact 14:141

Al-Sulaimani H, Joshi S, Al-Wahaibi Y, Al-Bahry S, Elshafie A, Bemani AA (2011) Microbial biotechnology for enhancing oil recovery: current developments and future prospects. Biotechnol Bioinf Bioeng 2:147-158

Al-Sulaimani H, Al-Wahaibi Y, Al-Bahry SN, Elshafie A, Al-Bemani A, Joshi S, Ayatollahi S (2012) Residual oil recovery via injection of biosurfactant, chemical surfactant and mixtures of both under reservoir condition: induced wettability and interfacial tension effects. SPE Reserv Eval Eng 15:210-217

Armstrong RT, Wildenschild D, Bay BK (2015) The effect of pore morphology on microbial enhanced oil recovery. J Petrol Sci Eng 130:16-25

Atlas RM (1975) Effects of temperature and crude oil composition on petroleum biodegradation. Appl Microbiol 30:396-403

Behlülgil K, Lu MTM (2002) Bacteria for improvement of oil recovery: a laboratory study. Energy Sourc 24:413-421

Beilen JB, Li Z, Smits TH, Witholt B (2003) Diversity of alkane hydroxylase systems in the environment. Oil Gas Sci Technol 58:427-440

Bentoa FM, Camargoa FA, Okekeb BC, Frankenberger WT Jr (2005) Diversity of biosurfactant producing microorganisms isolated from soils contaminated with diesel oil. Microbiol Res 160:249-255

Biria D, Roostaazad R, Darouneh E, Izadi H (2007) Analysis of MEOR efficiency to increase recovery in an Iranian reservoir. Scientia Iranica 14:161-168

Bryant RS (1987) Potential uses of microorganisms in petroleum recovery technology. Proc Okla Acad Sci Okla 67:97-104

Chandran P, Das N (2010) Biosurfactant production and diesel oil degradation by yeast species Trichosporon asahii isolated from petroleum hydrocarbon contaminated soil. Int J Eng Sci Technol 2:6942-6953

Cooper DG, Macdonald CR, Duff SJB, Kosaric N (1981) Enhanced production of surfactin from Bacillus subtilis by continuous product removal and metal cation addition. Appl Environ Microbiol 42:408-412

da Cruz GF, Angolini CF, de Oliveira LG et al (2010) Searching for monooxygenases and hydrolases in bacteria from an extreme environment. Appl Microbiol Biotechnol 87:319-329

Evans FF, Rosado AS, Sebastian GV, Casella R, Machado PLOA, Holmstrom C, Seldin L (2004) Impact of oil contamination and biostimulation on the diversity of indigenous bacterial communities in soil microcosms. FEMS Microbiol Ecol 49:295-305

Geetha SJ, Joshi SJ, Kathrotiya S (2013) Isolation and characterization of hydrocarbon degrading bacterial isolate from oil contaminated sites. APCBEE Procedia 5:237-241

Hamme JDV, Singh A, Ward OP (2003) Recent advances in petroleum microbiology. Microbiol Mol Biol Rev 67:503-549

Harris RE, McKay ID (1998) New applications for enzymes in oil and gas production. In: European petroleum conference, Society of Petroleum Engineers 50621-MS, pp 467-475

Hasanuzzaman M, Umadhay-Briones KM, Zsiros SM, Morita N, Nodasaka Y, Yumoto I, Okuyama H (2004) Isolation, identification, and characterization of a novel, oil-degrading bacterium, Pseudomonas aeruginosa T1. Curr Microbiol 49:108-114

Head IM, Jones DM, Larter SR (2003) Biological activity in the deep subsurface and the origin of heavy oil. Nature 426:344-352

Hozumi T, Tsutsumi H, Kono M (2000) Bioremediation on the shore after an oil spill from the Nakhodka in the Sea of Japan. I. chemistry and characteristics of heavy oil loaded on the
Nakhodka and bioderadation test by a bioremedation agent with microbiology culture in the laboratory. Mar Pollut Bull 40:308-314

Illias RM, Wei OS, Idris AK, Rahman WAWA (2001) Isolation and characterization of halotolerant aerobic bacteria from oil reservoir. J Teknologi 35:1-10

Joshi SJ, Desai AJ (2013) Bench-scale production of biosurfactants and its potential in Ex-Situ MEOR application. Soil Sedim Contam Int J 22:701-715

Joshi SJ, Geetha SJ, Desai AJ (2015) Characterization and application of biosurfactant produced by Bacillus licheniformis R2. Appl Biochem Biotechnol 177:346-361

Kebria DY, Khodadadi A, Ganjidoust H, Badkoubi A, Amoozegar MA (2009) Isolation and characterization of a novel native Bacillus strain capable of degrading diesel fuel. Int J Environ Sci Technol 6:435-442

Kubota K, Koma D, Matsumiya Y, Chung SY, Kubo M (2008) Phylogenetic analysis of long-chain hydrocarbon-degrading bacteria and evaluation of their hydrocarbon-degradation by the 2,6-DCPIP assay. Biodegradation 19:749-757

Le JJ, Wu XL, Wang R, Zhang JY, Bai LL, Hou ZW (2015) Progress in pilot testing of microbial-enhanced oil recovery in the Daqing oilfield of north China. Int Biodeterior Biodegrad 97:188-194

Maeng JH, Sakai Y, Tani Y, Kato AN (1996) Isolation and characterization of a novel oxygenase that catalyzes the first step of $n$-alkane oxidation in Acinetobacter sp. strain M-1. J Bacteriol 178:3695-3700

Malik S, Zhang YM, Asimi MA, Gould TL (2010) Modified SADG in multizones at Mukhazina. SPE EOR conference. Oil and Gas West Asia, Muscat, Oman

Mandri T, Lin J (2007) Isolation and characterization of engine oil degrading indigenous microorganisms in Kwazulu-Natal, South Africa. Afr J Biotechnol 6:023-027

Montiel C, Quintero R, Aburto J (2009) Petroleum biotechnology: technology trends for the future. Afr $\mathrm{J}$ Biotechnol 8:2653-2666

Morán AC, Olivera N, Commendatore M, Esteves JL, Siñeriz F (2000) Enhancement of hydrocarbon waste biodegradation by addition of a biosurfactant from Bacillus subtilis O9. Biodegradation 11:65-71

Mukherjee S, Das P, Sen R (2009) Rapid quantification of a microbial surfactant by a simple turbidometric method. J Microbiol Methods 76:38-42

Nadyal M, Thurber SS, AL-Hinai KM, Jaffer NA (1983) Development of heavy oil reserves in south Oman. In: Middle East oil technical conference and exhibition. Society of Petroleum Engineers, Manama

Nazina T, Sokolova D, Shestakova N, Grigoryan A, Mikhaliova E et al (2005) The phylogenetic diversity of aerobic organotrophic bacteria from the Dagang high-temperature oil field. Microbiology $74: 343-351$

Nkwelang G, Kamga HF, Nkeng GE, Antai SP (2008) Studies on the diversity, abundance and succession of hydrocarbon utilizing microorganisms in tropical soil polluted with oily sludge. Afr J Biotechnol 7:1075-1080

Paul JH, Jeffrey WH (1985) Evidence for separate adhesion mechanisms for hydrophilic and hydrophobic surfaces in Vibrio proteolytica. Appl Environ Microbiol 50:431-437

Premuzic ET, Lin MS (1999) Induced biochemical conversion of heavy crude oils. J Petrol Sci Eng 22:171-180

Rodrigues LR, Teixeira JA, Van Der Mei HC, Oliveira R (2006) Physicochemical and functional characterization of a biosurfactant produced by Lactococcus lactis 53. Coll Surf B 49:79-86

Satpute SK, Bhawsar DB, Dhakephalkar PK, Chopade BA (2008) Assessment of different screening method of selecting biosurfactant producing marine bacteria. Indian J Mar Sci 37:243-250 
Saul DJ, Aislabie JM, Brown CE, Harris L, Foght JM (2005) Hydrocarbon contamination changes the bacterial diversity of soil from around Scott Base, Antarctica. FEMS Microbiol Ecol 53:141-155

Sen R (2008) Biotechnology in petroleum recovery: the microbial EOR. Prog Energy Combust Sci 34:714-724

Seo JS, Keum YS, Harada RM, Li QX (2007) Isolation and characterization of bacteria capable of degrading polycyclic aromatic hydrocarbons (PAHs) and organophosphorus pesticides from PAH-contaminated soil in Hilo, Hawaii. J Agric Food Chem 55:5383-5389

Sepahy AA, Assadi MM, Saggadian V, Noohi A (2005) Production of biosurfactant from Iranian oil fields by isolated Bacilli. Int $\mathbf{J}$ Environ Sci Technol 1:287-293

Surasani VK, Li L, Ajo-Franklin JB, Hubbard C, Hubbard SS, Wu Y (2013) Bioclogging and permeability alteration by L. mesenteroides in a sandstone reservoir: a reactive transport modeling study. Energy Fuels 27:6538-6551

Tamura K, Peterson D, Peterson N, Stecher G, Nei M, Kumar S (2011) MEGA5: molecular evolutionary genetics analysis using maximum likelihood, evolutionary distance, and maximum parsimony methods. Mol Biol Evol 28:2731-2739

Throne-Holst M, Wentzel A, Ellingsen TE, Kotlar HK, Zotchev SB (2007) Identification of novel genes involved in long-chain $n$ alkane degradation by Acinetobacter sp. Strain DSM 17874. Appl Environ Microbiol 73:3327-3332
Ting ASY, Tan CHC, Aw CS (2009) Hydrocarbon-degradation by isolate Pseudomonas lundensis UTAR FPE2. Malays J Microbiol 5:104-108

Vazquez-Duhalt R, Torres E, Valderrama B, Borgne SL (2002) Will biochemical catalysis impact the petroleum refining industry? Energy Fuels 16:1239-1250

Vilcáez J, Li L, Wu D, Hubbard SS (2013) Reactive transport modeling of induced selective plugging by leuconostoc mesenteroides in carbonate formations. Geomicrobiol J 30:813-828

Wu Y, Surasani VK, Li L, Hubbard SS (2014) Geophysical monitoring and reactive transport simulations of bioclogging processes induced by Leuconostoc mesenteroides. Geophysics 79:E61-E73

Yakimov MM, Amro MM, Bock M, Bosker K, Frederickson HL, Kessel DG, Timmis KN (1997) The potential of Bacillus licheniformis strain for in situ enhanced oil recovery. J Petrol Sci Eng 18:147-160

Yamane K, Maki H, Nakayama T, Nakajima T, Nomura N, Uchiyama H, Kitaoka M (2008) Diversity and similarity of microbial communities in petroleum crude oils produced in Asia. Biosci Biotechnol Biochem 72:2831-2839

Zhang H, Kallimanis A, Koukkou A, Drainas C (2004) Isolation and characterization of novel bacteria degrading polycyclic aromatic hydrocarbons from polluted Greek soils. Appl Microbiol Biotechnol 65:124-131 